\title{
Comparative Analysis of the Dynamics of Indicator Changes GDP per Capita in the Regions of Greece, Germany and Romania
}

\author{
Agata SURÓWKA \\ Rzeszow University of Technology, Rzeszow, Poland; agasur@prz.edu.pl
}

\begin{abstract}
Recently, the subject of economic development of regions has a special place in economic literature. In numerous studies we find many ways to measure this phenomenon using various indicators. In most of them, regional GDP per capita is the main and most commonly used measure for measuring economic growth and development of the regions of the European Union. Sometimes it is treated as the simplest synthetic measure of regional development or convergence processes. It was used in the text to verify the dynamics of changes (2008-2017) of the relative position of the regions of Greece, Germany and Romania in transition matrices for Eurostat data. The test is a continuation of the research carried out by the author for Polish, Bulgarian, Slovak, Lithuanian regions, and the results of which have been published. The researchers' approach allowed to verify the degree of diversification of the economic strength of the studied regions and to conduct a comparative analysis of the dynamics of changes in the general distribution of income and the location of the regions studied in the transition matrices for regions of selected countries (NUTS2).
\end{abstract}

Keywords: GDP per capita; regional development; quantitative methods; competitiveness

JEL Classification: R11; O11

\section{Introduction}

Recently, many studies have been prepared on the economic development of the regions. (Muayedovich Kaziyev, Valer'yevna Kaziyeva and Yur'yevna 2018; Avram 2016). GDP per capita is an important indicator of economic growth, competitiveness and regional development of the regions of the European Union (Nadaud and Bouba-Olga 2019; Popescu 2017; Podstawka and Suchodolski 2018). As some authors note, competitiveness is measured by the GDP per capita indicator and "divided" into two components determining its level; which is labor productivity and the rate of economic activity of the population in the region - employment rate (Pietrzyk 2000). This means that for a region to be considered competitive it must have at the same time high productivity (and the associated high quality of employment) as well as sufficient number of jobs (Pietrzyk 2000).

Recently, the minds of researchers are dealing with the most difficult problem, which is the subject of many discussions, namely the problem of measuring regional development using GDP per capita (Surówka and Prędka 2016; Surówka 2019; Nadaud and Bouba-Olga 2019). By analyzing historical statistical data in dynamic terms, we observe that when it comes to interregional differences in indicators in the EU, they are (as is commonly known) very large in terms of both the absolute level and the rate of growth. Likewise, strongly differentiated was formation of the growth rate of components (productivity and employment) and even that in regions with a similar GDP per capita indicator (Nadaud and Bouba-Olga 2019). For example, in the Portuguese and Spanish regions similar in this respect, in the first case we had to deal with very low productivity (around $60 \%$ of the EU average compared to $90 \%$ for Spain) and a relatively high level of employment (Pietrzyk 2000). The opposite problem is observed for Spain, therefore the main challenge for Spain should be to increase the size of employment, and for Portugal the problem is to increase labor productivity. Observations, however, prove that in both countries the evolution is taking place in the right direction. Nevertheless, differences existing in both countries in relation to the EU average suggest that catching up in both cases will be a long-term process (Pietrzyk 2000; Badoiu Catalina 2017). The situation in Greece was 
less favorable, where both productivity and employment levels are very low. Analyzing historical data, we note that in terms of the first indicator Greece, next to the Portuguese regions, is at the lowest level in the EU, but unlike Portugal, at the same time, it achieves a low growth rate. In addition, in many regions of the country the share of employees in the number of people of working age does not exceed $50 \%$ for all of Greece.

\section{Methodology}

Given the above, it is justified to develop new tools for shaping the examined trends (Muayedovich Kaziyev, Valer'yevna Kaziyeva and Yur'yevna 2018). An in-depth analysis of this phenomenon induced the author to attempt research on a given topic. The text analyzes the dynamics of changes in income distribution measured using GDP per capita for regions of selected European Union countries (Greece, Germany, Romania). The transition matrix was used as the research tool. As some authors note, most studies are limited to assessing and analyzing global trends and failing to distinguish between situations in which regions maintain their relative position; from situations where the overall distribution of income changes little, but the location of some regions changes significantly. In this case, individual regions may significantly differ from each other in their pace of development, even in periods when no convergence has been detected. As some authors rightly point out, the method that allows verification of these trends is the construction of a transition matrix, which makes it possible to track the relative change in position of regions over time (Lewandowski, 2011). Transition matrices were determined in the studying dynamic terms for the regions of Greece, Germany and Romania (2008-2017) (Surówka and Prędka 2016).

\section{GDP per Capita as a Determinant for the Economic Development of Greece, Germany and Romania - Results of Empirical Research}

Transition matrices are tools that express the frequency with which in the same period of time, regions from any income class remain in the same class or move to other classes. Diego Puga constructed a matrix of potential GDP per capita transitions in relation to the EU average, which analyzed changes in the location of regions between 1987 and 1995. The presented description of the method is only brief; more details can be found in the economic literature (Lewandowski 2011); (Surówka and Prędka 2016; Lai and Leone and Zoppi 2017). In the study, dynamic transition matrices were determined for the regions of Greece, Germany and Romania (2008-2017). The typologies of Greece regions according to their position in the designated transition matrices are presented in the table below (see Table 1). The presentation of results was preceded by an illustration of the administrative division of the countries studied on figures 1, 5 and 7.

Table 1. Table description include reference to its source if the figure does not come from your original research.

\begin{tabular}{|c|c|c|c|c|c|c|c|}
\hline \multirow{8}{*}{$\begin{array}{l}\text { GDP } \\
\text { per } \\
\text { capita } \\
2008\end{array}$} & \multirow{3}{*}{$\begin{array}{c}\begin{array}{c}\text { Number } \\
\text { of } \\
\text { districts }\end{array} \\
8\end{array}$} & \multirow{3}{*}{$\begin{array}{c}\text { GDP per capita } \\
\text { interval } \\
\text { (national average) }\end{array}$} & \multicolumn{5}{|c|}{ GDP per capita 2009} \\
\hline & & & & & & & \\
\hline & & & 1 & & & & \\
\hline & 3 & $0,6-0,75$ & 0,33 & 0,67 & & & \\
\hline & 0 & $0,75-1,00$ & & & & & \\
\hline & 0 & $1,00-1,3$ & & & & & \\
\hline & 2 & $1,3+$ & & & & & 1 \\
\hline & \multicolumn{2}{|c|}{ GDP per capita interval } & $0-0,6$ & $0,6-0,75$ & $0,75-1,0$ & $1,0-1,3$ & $1,3+$ \\
\hline & $\begin{array}{c}\text { Number } \\
\text { of } \\
\text { districts }\end{array}$ & $\begin{array}{c}\text { GDP per capita } \\
\text { interval } \\
\text { (national average) }\end{array}$ & \multicolumn{5}{|c|}{ GDP per capita 2010} \\
\hline GDP & 9 & $0-0,6$ & & 0,889 & 0,111 & & \\
\hline per & 2 & $0,6-0,75$ & & 1 & & & \\
\hline capita & 0 & $0,75-1,00$ & & & & & \\
\hline
\end{tabular}




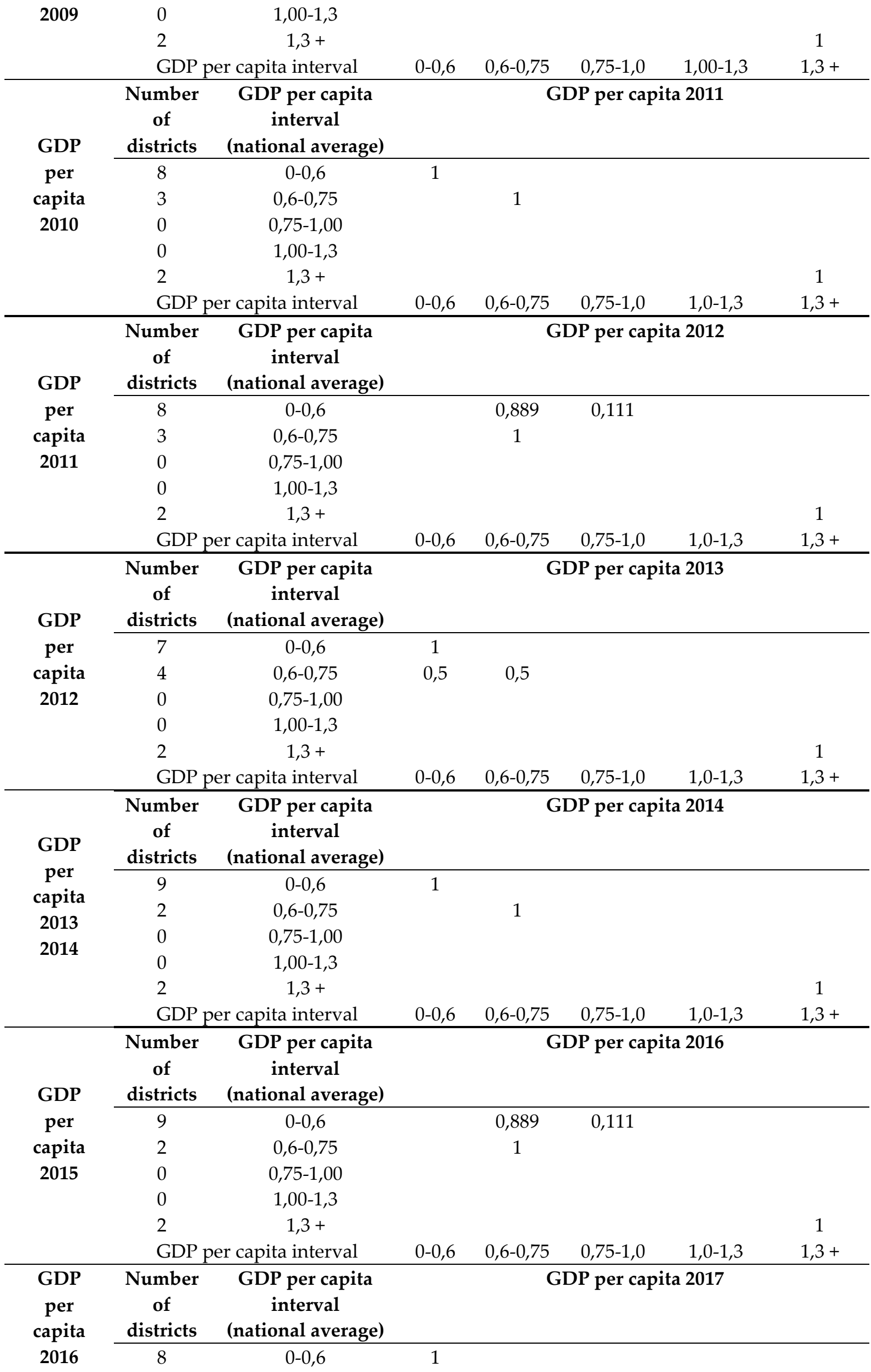




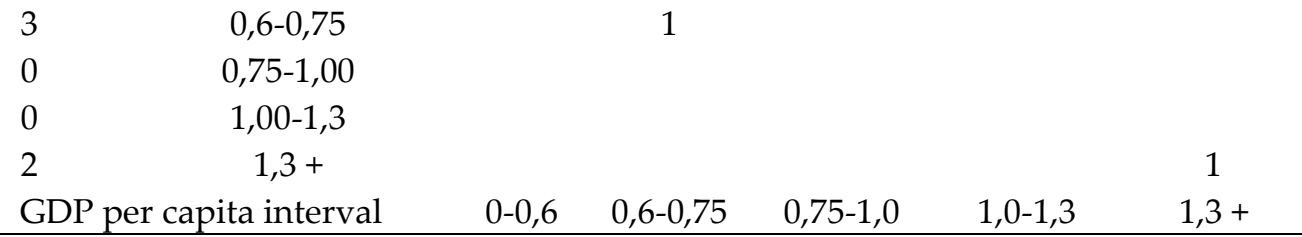

The main diagonal of the matrix shows the share of regions that were in the same income range in both periods studied. Analyzing the above matrix (see Table 1), we note that most regions of Greece did not change their position, being in the same income range in designated transition matrices. Based on the analysis of data and the results of research so far, it can be concluded that the position of individual regions of Greece is stable in the period adopted for the study; there is no significant mobility of regions with national averages.

Given the above, it can be concluded that the regions of Greece are developing at an analogical pace; there is high income stability. Some change can only be seen in the periods: 2008-2009; when the Dytiki Ellada region (see Fig. 2) shifted from the higher income range (0.6-0.75) to the lower (0-0.6) and 2009-2010; when the region moved again to a higher income range (0.6-0.75) in the transition matrix. Another change in the range of this region (see Fig. 3) took place in the period 2012-2013; when it shifted again to a lower level (0-0.6) and its position did not change until the end of the examined period. Changes can also be observed in the Sterea Ellada region (see Fig. 3) in the period: 2011-2012, when the region shifted from a lower one $(0-0.6)$ to the higher $(0.6-0.75)$ income range, then in the following year it returned to the lower range again and remained at this level for three consecutive years. In the period 2015-2016 there was a new change; Sterea Ellada region shifted back to a higher range (0.6-0.75). Data analysis suggests that the most, because eight examined objects (Anatoliki Makedonia, Dytiki Makedonia, Ipeiros, Ionia Nisia, Sterea Ellada, Peloponnisos, Voreio Aigaiou, Notio Aigaiou, Kriti) were in the ranges with the lowest GDP per capita values compared to other Greek regions. In the period 2008-2017, none of these regions changed their position in the designated transition matrices.

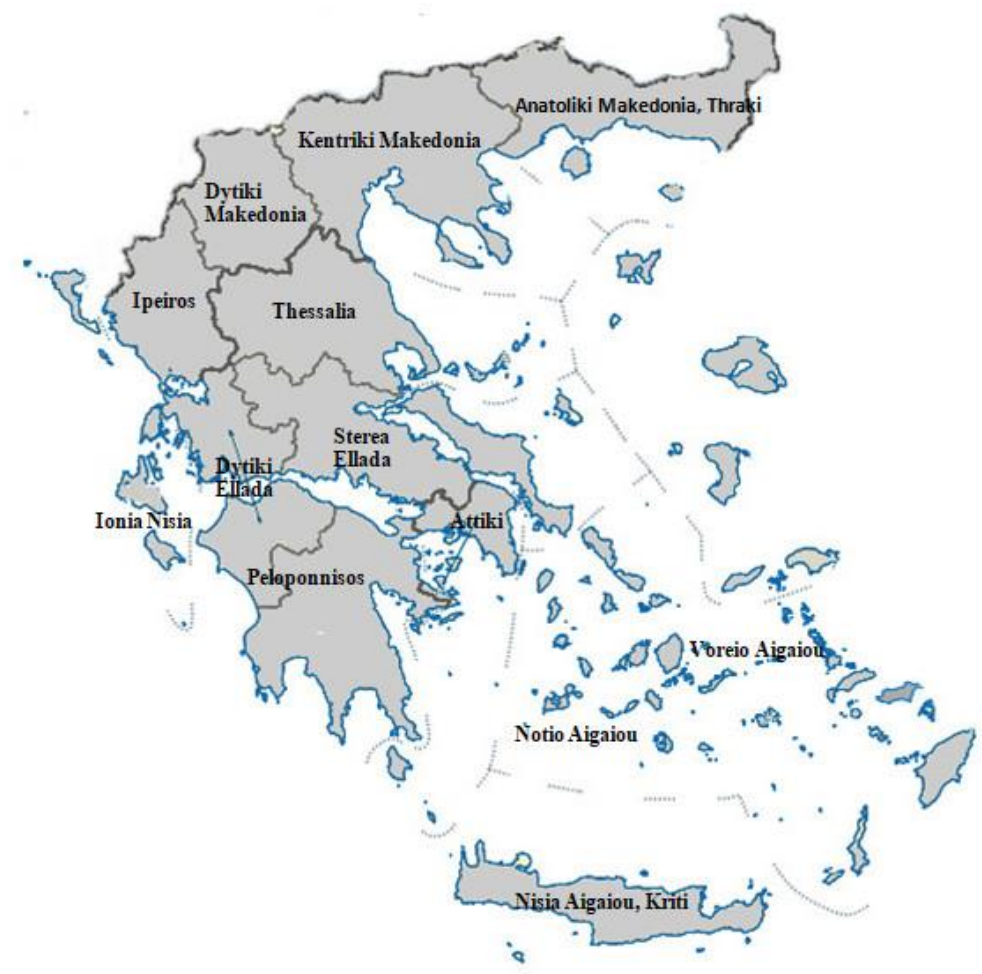

Figure 1. Administrative map of Greece. 

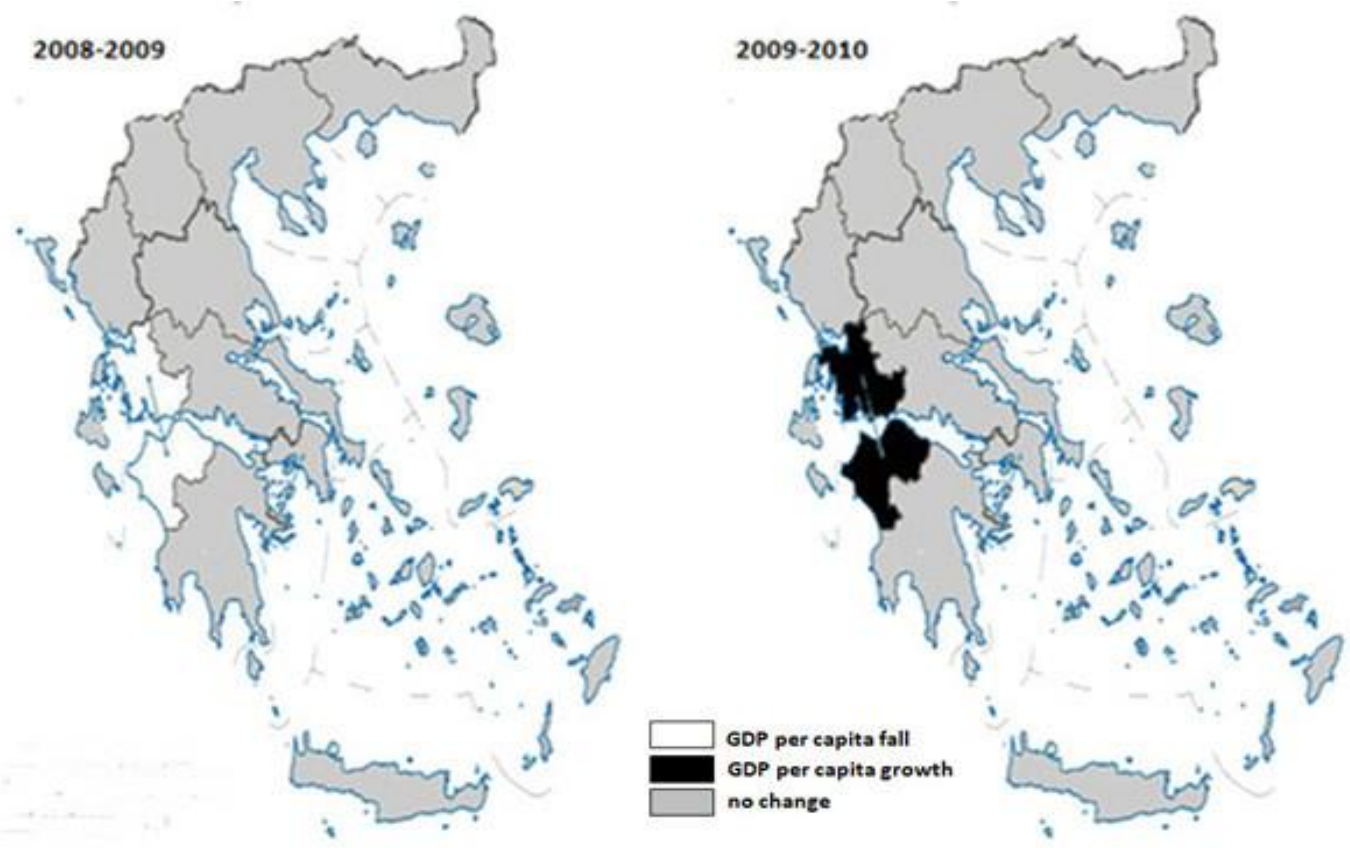

Figure 2. Map of potential transitions for Greece sub-regions in the 2008-2010.

The results obtained are presented graphically in Figures 1-4. The stability of the ranges occupied by the Greek regions also suggests that the analysis of the transition matrix for these regions shows only the static dimension of this phenomenon; despite the observed increase in the studied variable for all research units in the period adopted for the audit. A group of leading regions has developed (Kentriki Makedonia, Attiki) whose position in transition matrices has not changed throughout the entire research period.
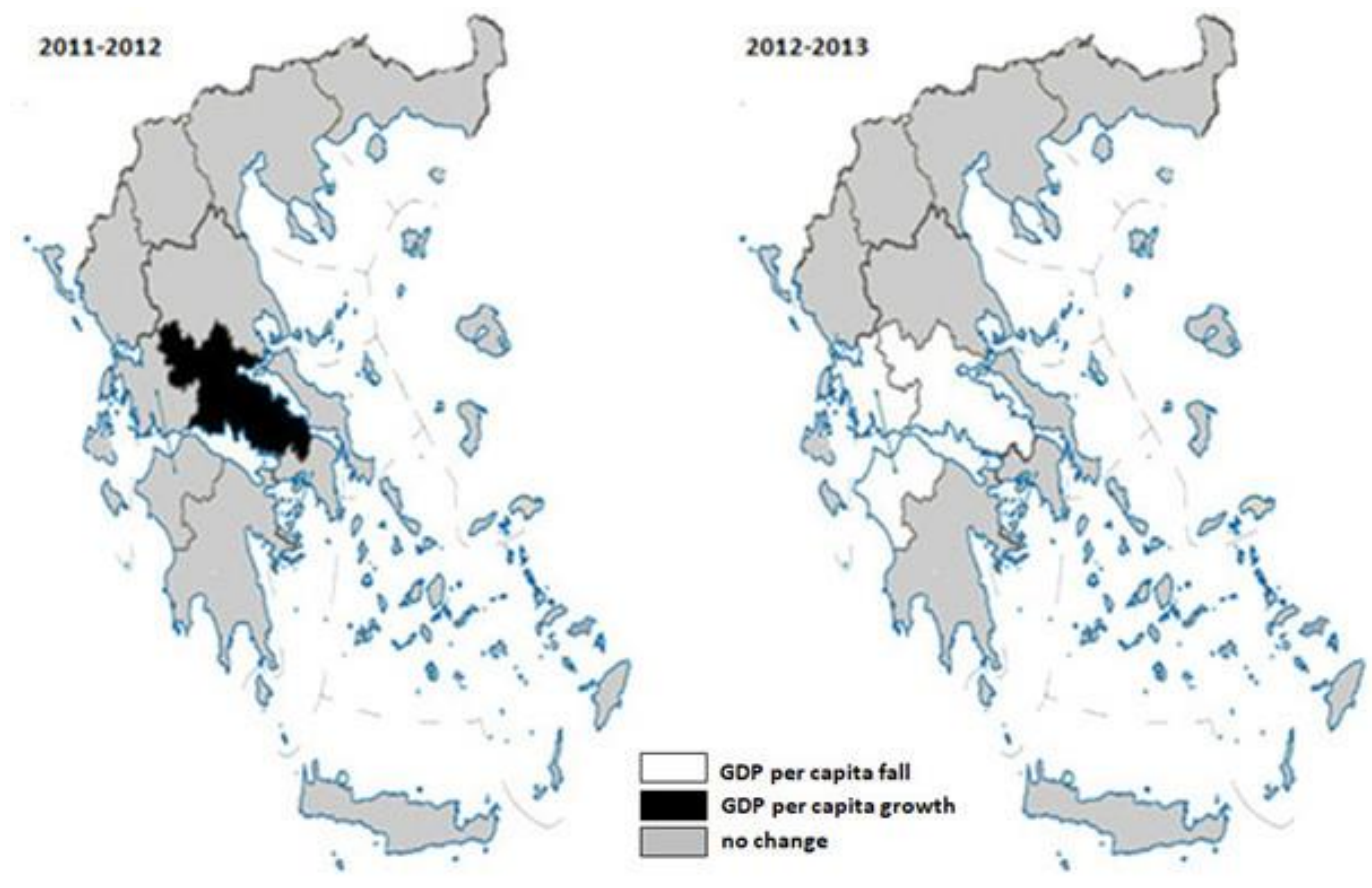

Figure 3. Map of potential transitions for Greece sub-regions in the 2011-2013. 


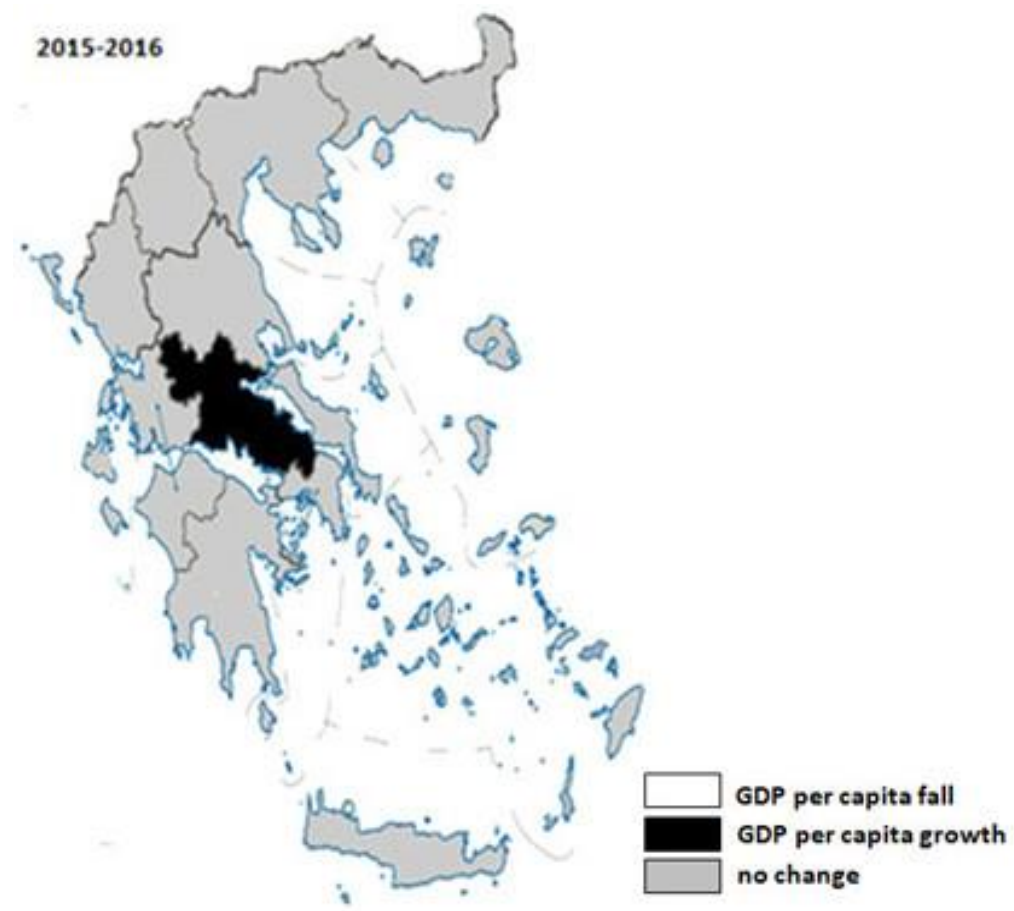

Figure 4. Map of potential transitions for Greece sub-regions in the 2015-2016.

A similar study was carried out for regions in Germany. Analyzing the results obtained, we can conclude that, as in the case of Greece, the majority of objects in Germany did not change their position, being in the same income range in designated transition matrices.

In the period 2008-2009, the position changed in transition matrices it concerned the Unterfranken object (see Fig.6). This region changed its position and there was a shift from 0.6-0.75 to a lower range of 0-0.6. In 2009-2010, out of two regions that were in the range of 0.6-0.75 in 2009, the change in the income group concerned the Braunschweig region; shifting to a higher income range (0.75-1.00). During this period there was a shift from the first (0-0.6) to the second (0.6-0.75) compartment of the Unterfranken object. In the period 2010-2017, no region changed its position in constructed transition matrices. As many as fourteen regions were located in the lowest income range in the entire research period (Niederbayern, Oberpfalz, Oberfranken, Bremen, Gießen, Kassel, Mecklenburg-Vorpommern, Lüneburg, Koblenz, Trier, Saarland, Dresden, Chemnitz, Leipzig).

Table 2. A matrix of potential transition per capita for German regions with regard to medium domestic (2008-2017).

\begin{tabular}{|c|c|c|c|c|c|c|c|}
\hline \multirow{5}{*}{$\begin{array}{l}\text { GDP } \\
\text { per } \\
\text { capita } \\
2008\end{array}$} & \multirow{3}{*}{$\begin{array}{c}\begin{array}{c}\text { Number of } \\
\text { districts }\end{array} \\
14\end{array}$} & \multirow{3}{*}{$\begin{array}{c}\text { GDP per capita } \\
\text { interval } \\
\text { (national average) } \\
0-0,6\end{array}$} & \multicolumn{5}{|c|}{ GDP per capita 2009} \\
\hline & & & & & & & \\
\hline & & & 1 & & & & \\
\hline & 3 & $0,6-0,75$ & 0,33 & 0,67 & & & \\
\hline & 9 & $0,75-1,00$ & & & 1 & & \\
\hline & 3 & $1,00-1,3$ & & & & 1 & \\
\hline & 9 & $1,3+$ & & & & & 1 \\
\hline & \multicolumn{2}{|c|}{ GDP per capita interval } & $0-0,6$ & $0,6-0,75$ & $0,75-1,0$ & $1,0-1,3$ & $1,3+$ \\
\hline $\begin{array}{l}\text { GDP } \\
\text { per } \\
\text { capita }\end{array}$ & $\begin{array}{c}\text { Number of } \\
\text { districts }\end{array}$ & $\begin{array}{c}\text { GDP per capita } \\
\text { interval } \\
\text { (national average) }\end{array}$ & & GDI & per capit & 2010 & \\
\hline \multirow[t]{2}{*}{2009} & 15 & $0-0,6$ & 0,93 & 0,07 & & & \\
\hline & 2 & $0,6-0,75$ & & 0,5 & 0,5 & & \\
\hline
\end{tabular}




\begin{tabular}{|c|c|c|c|c|c|c|c|}
\hline & 9 & $0,75-1,00$ & \multicolumn{5}{|c|}{1} \\
\hline & 3 & $1,00-1,3$ & & & \multicolumn{3}{|c|}{1} \\
\hline & 9 & $1,3+$ & & & & & 1 \\
\hline & \multicolumn{2}{|c|}{ GDP per capita interval } & $0-0,6$ & $0,6-0,75$ & $0,75-1,0$ & $1,0-1,3$ & $1,3+$ \\
\hline $\begin{array}{l}\text { GDP per } \\
\text { capita } \\
2010\end{array}$ & $\begin{array}{l}\text { Number of } \\
\text { districts }\end{array}$ & $\begin{array}{c}\text { GDP per capita } \\
\text { interval } \\
\text { (national average) }\end{array}$ & & $\begin{array}{r}\mathrm{G} \\
1,2012,2 \mathrm{C}\end{array}$ & $\begin{array}{l}\text { P per capi } \\
3,2014,20\end{array}$ & 5,2016 , & \\
\hline 2011 & 14 & $0-0,6$ & 1 & & & & \\
\hline 2012 & 2 & $0,6-0,75$ & & 1 & & & \\
\hline 2013 & 10 & $0,75-1,00$ & & & 1 & & \\
\hline 2014 & 3 & $1,00-1,3$ & & & & 1 & \\
\hline 2015 & 9 & $1,3+$ & & & & & 1 \\
\hline 2016 & \multicolumn{2}{|c|}{ GDP per capita interval } & $0-0,6$ & $0,6-0,75$ & $0,75-1,0$ & $1,0-1,3$ & $1,3+$ \\
\hline
\end{tabular}

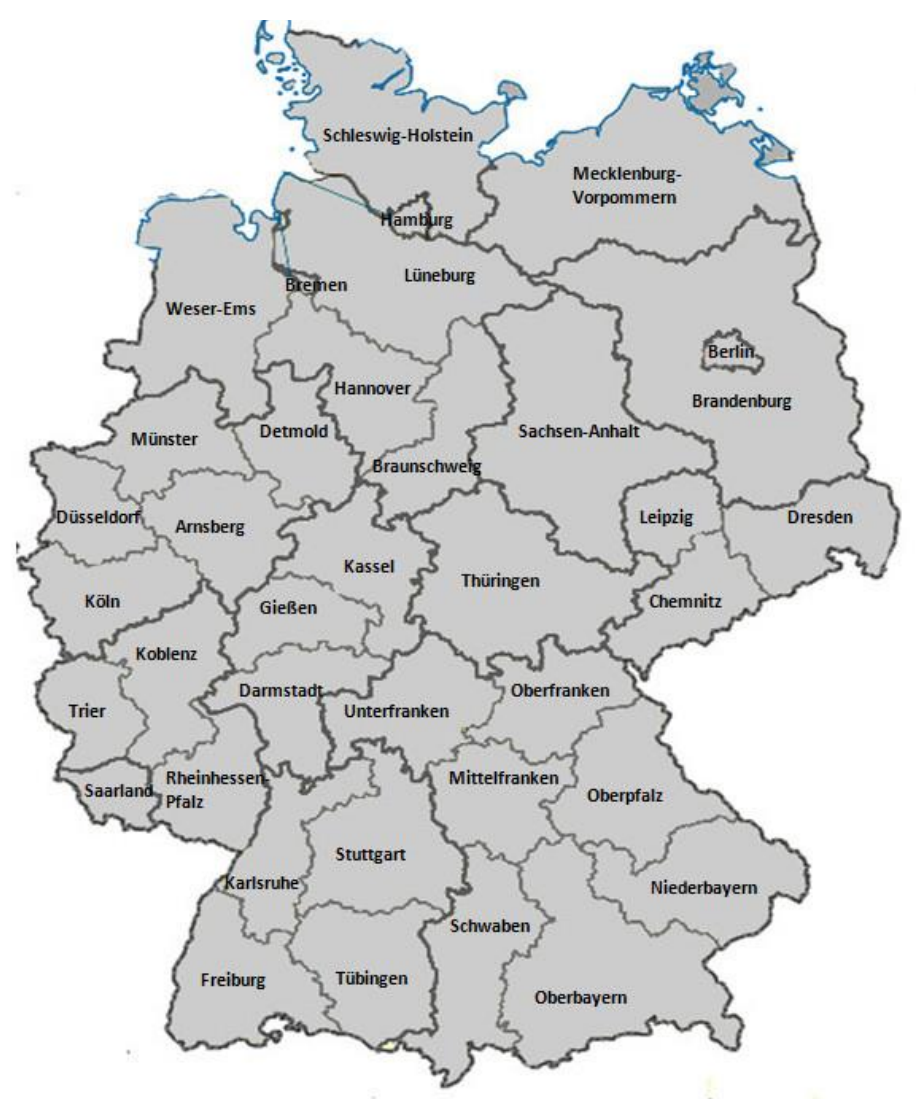

Figure 5. Administrative map of Germany. 

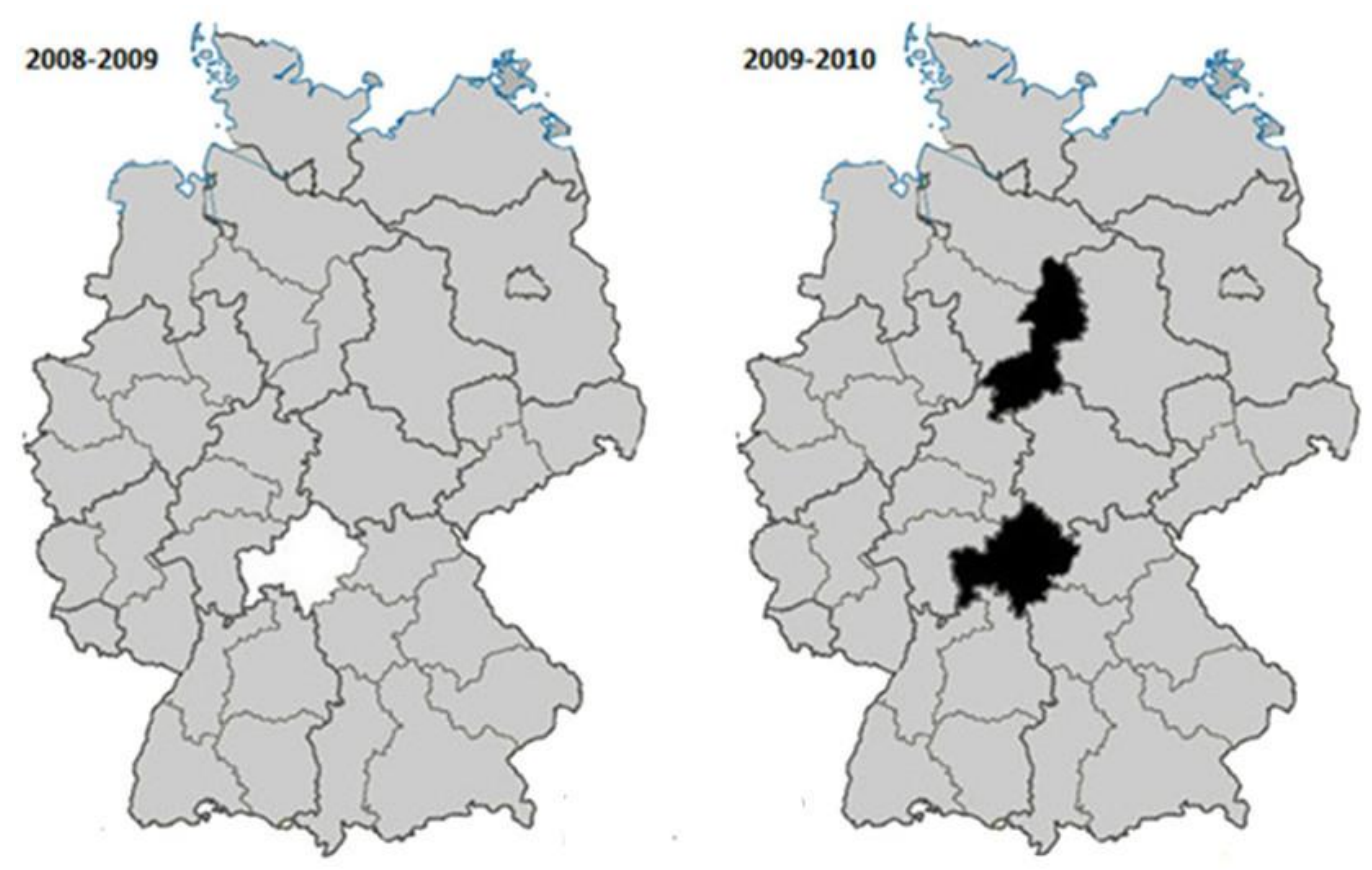

Figure 6. Map of potential transitions for Germany sub-regions in the 2008-2010.

Table 3. A matrix of potential transition per capita for Romania regions with regard to medium domestic (2008-2017).

\begin{tabular}{|c|c|c|c|c|c|c|c|}
\hline \multirow{8}{*}{$\begin{array}{l}\text { GDP } \\
\text { per } \\
\text { capita } \\
2008\end{array}$} & \multirow{3}{*}{$\begin{array}{c}\text { Number of } \\
\text { districts } \\
0\end{array}$} & \multirow{3}{*}{$\begin{array}{c}\begin{array}{c}\text { GDP per capita } \\
\text { interval } \\
\text { (national average) }\end{array} \\
0-0,6\end{array}$} & \multicolumn{5}{|c|}{ GDP per capita 2009} \\
\hline & & & & & & & \\
\hline & & & & & & & \\
\hline & 1 & $0,6-0,75$ & & 1 & & & \\
\hline & 5 & $0,75-1,00$ & & & 1 & & \\
\hline & 1 & $1,00-1,3$ & & & & 1 & \\
\hline & 1 & $1,3+$ & & & & & 1 \\
\hline & \multicolumn{2}{|c|}{ GDP per capita interval } & $0-0,6$ & $0,6-0,75$ & $0,75-1,0$ & $1,0-1,3$ & $1,3+$ \\
\hline GDP & $\begin{array}{c}\text { Number of } \\
\text { districts }\end{array}$ & $\begin{array}{c}\text { GDP per capita } \\
\text { interval } \\
\text { (national average) }\end{array}$ & & GDP & er capita & 10 & \\
\hline per & 0 & $0-0,6$ & & & & & \\
\hline capita & 1 & $0,6-0,75$ & & 1 & & & \\
\hline \multirow[t]{4}{*}{2009} & 5 & $0,75-1,00$ & & & 1 & & \\
\hline & 1 & $1,00-1,3$ & & & 1 & 0 & \\
\hline & 1 & $1,3+$ & & & & & 1 \\
\hline & \multicolumn{2}{|c|}{ GDP per capita interval } & $0-0,6$ & $0,6-0,75$ & $0,75-1,0$ & $1,0-1,3$ & $1,3+$ \\
\hline GDP & $\begin{array}{l}\text { Number of } \\
\text { districts }\end{array}$ & $\begin{array}{c}\text { GDP per capita } \\
\text { interval } \\
\text { (national average) }\end{array}$ & & GDP & er capita & 11 & \\
\hline per & 0 & $0-0,6$ & & & & & \\
\hline capita & 1 & $0,6-0,75$ & & 1 & & & \\
\hline \multirow[t]{4}{*}{2010} & 6 & $0,75-1,00$ & & & 0,833 & 0,167 & \\
\hline & 0 & $1,00-1,3$ & & & & 1 & \\
\hline & 1 & $1,3+$ & & & & & 1 \\
\hline & \multicolumn{2}{|c|}{ GDP per capita interval } & $0-0,6$ & $0,6-0,75$ & $0,75-1,0$ & $1,0-1,3$ & $1,3+$ \\
\hline
\end{tabular}




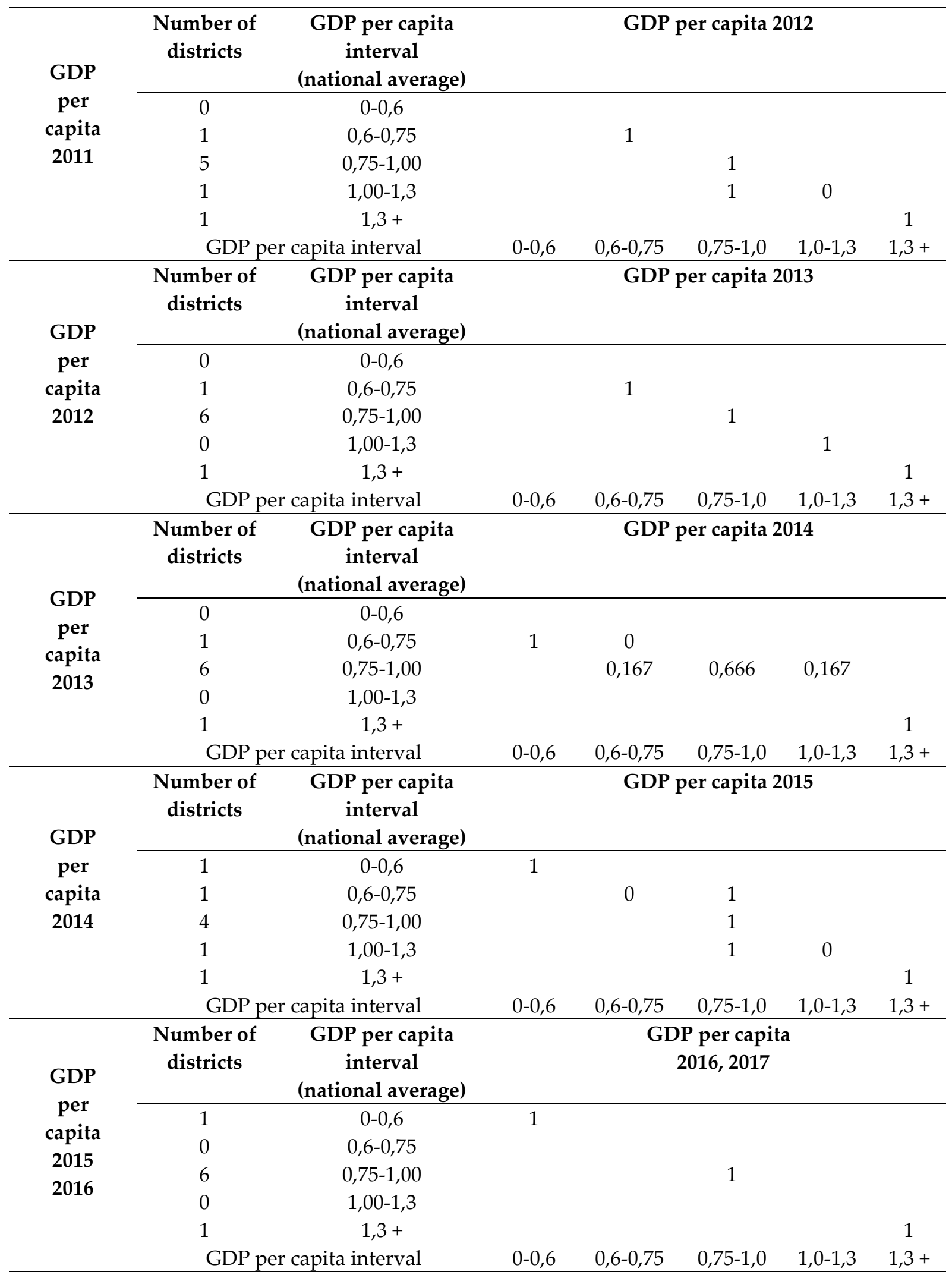

Romania was the third country that became a source of interest in the study. In the entire research period, the change in income position related to only three facilities (Sud - Muntenia, Sud-Vest Oltenia, Vest). In the period 2009-2010, a decrease in the Sud - Muntenia position in transition matrices was observed. This facility in the period 2009-2010 moved to the middle range (0.75-1.00). In the next period (2010-2011) it returned to the higher income range (1.00-1.3), and then in the next one (2011-2012) this object was moved back to the lower income group. Another change in the income group for this object 
can be observed in 2014 compared to the previous period (a shift from the range (0.75-1.00) to the range (1.00-1.3)). In 2014, the Sud-Vest Oltenia region shifted from the second income position (0.6-0.75) to the first $(0-0.6)$ and remained at this level until the end of the adopted research period. In turn, the Vest region in 2014 recorded a decrease by one position to the second level (0.6-0.75), then in the following year it returned to the initial level (0.75-1.00). Analyzing statistical data, we note that only one region (Bucuresti - Ilfov) throughout the entire research period it was in the highest income group. No object was found in the lowest income range in the whole research period. The latest empirical research also confirmed regional divergence based on different time spans (Goschin Zizi 2017).

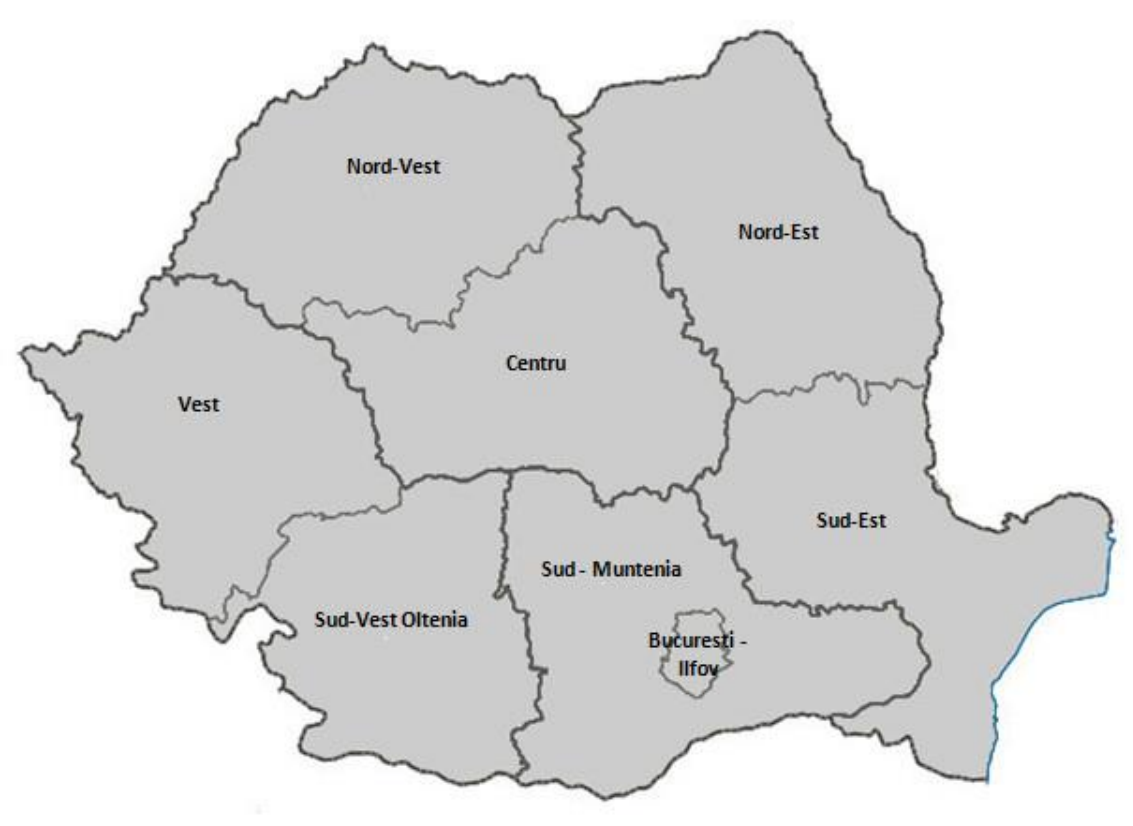

Figure 7. Administrative map of Romania.
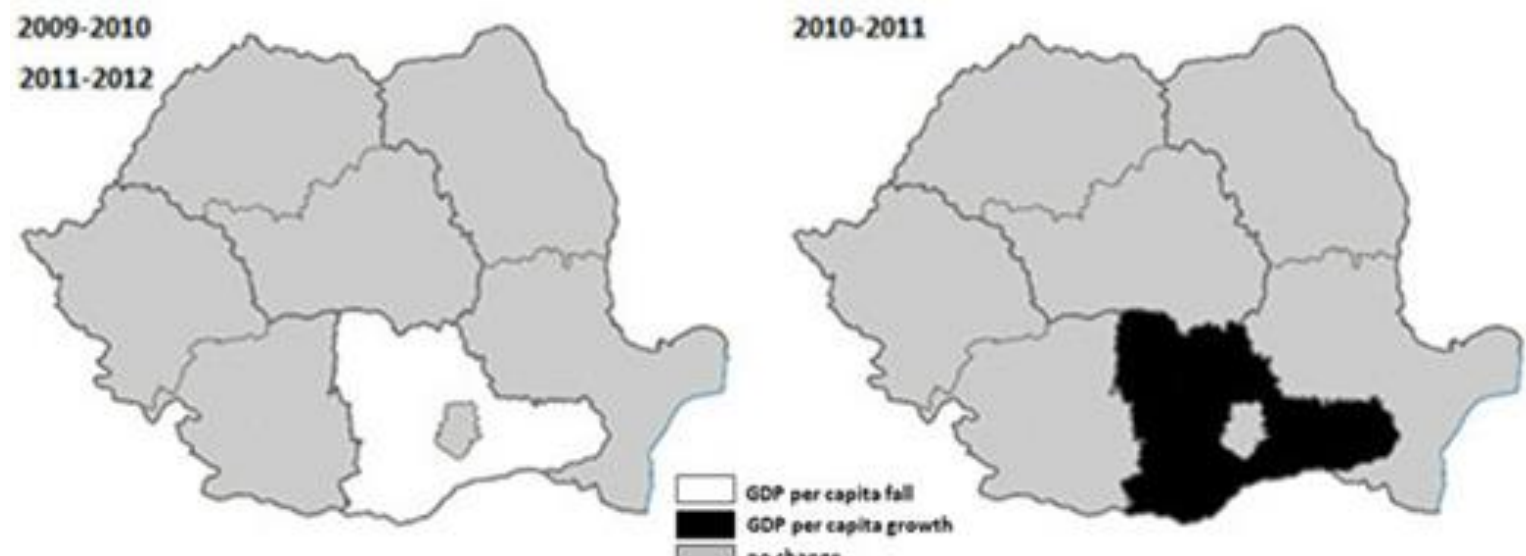

Figure 8. Map of potential transitions for Romanian sub-regions in the 2009-2012. 


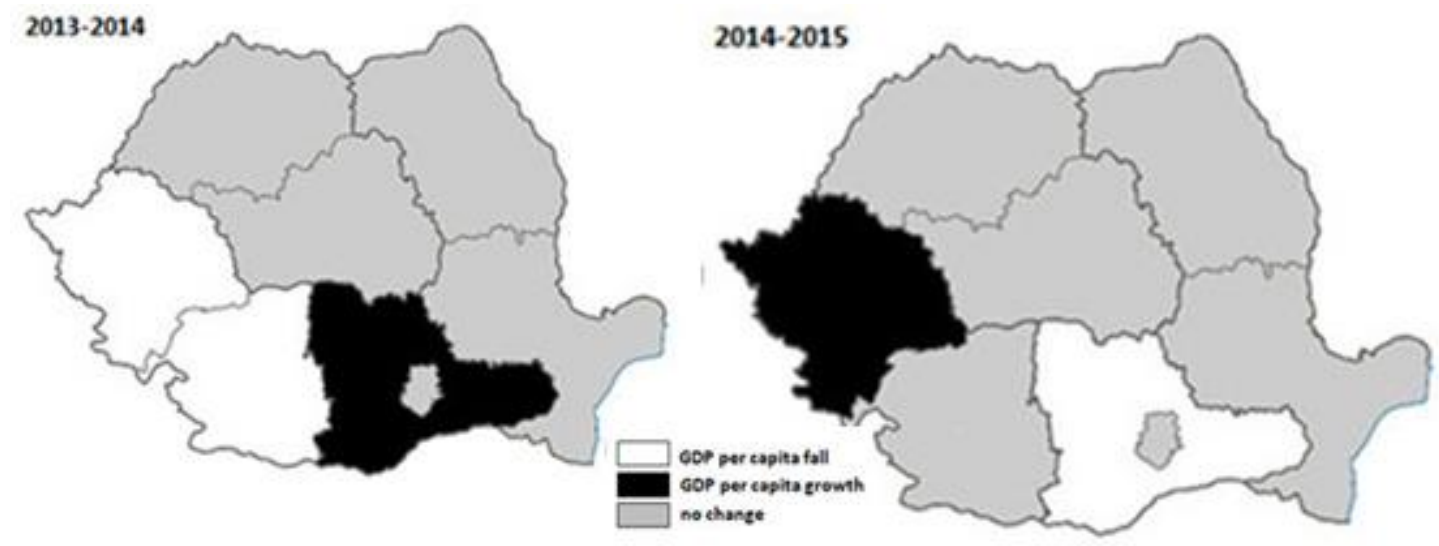

Figure 9. Map of potential transitions for Romanian sub-regions in the 2013-2015.

\section{Discussion and Conclusions}

As some Authors note it was found that economic growth positively influences income inequalities as well as decreases the share of population under the poverty threshold in all regions. However, the development differs across regions (Michálek Anton and Výboštok Ján 2018). During the author's own research, this problem was taken up by her in publications. This article is a continuation of the author's own research in the field of regional development, innovation and competitiveness of European Union regions (Surówka 2014; Surówka 2015). The purpose of the article was to present a different way of measuring the GDP per capita in dynamic terms. Transition matrices were used to achieve the goal. The research approach used in the study enabled verification of the degree of diversification of the economic power of regions of three European Union countries (Greece, Germany and Romania). Thanks to the dynamic analysis, it was possible to compare the dynamics of changes in the general distribution of income and the location of the examined units in the constructed transition matrices. Analyzing the results presented in the text, we note that the position of most of the analyzed regions of each country (Romania, Greece and Germany) in the designated matrices is fixed. A group of leading regions developed in each country, which were in the highest income range in the entire research period. In the case of Greece, these are two of the thirteen regions (which is 15.4 percent). In Germany, nine out of thirty-eight. Which is 23.7 percent, therefore more compared to Greece. Comparing the three countries, the lowest percentage of regions classified in the highest income bracket in the constructed transition matrices was observed in Romania. As some Authors note territorial economic development in Romania has led to the existence and intensification of gaps, thus it is very important to reduce and manage them by implementing coherent programs designed for continuous and sustainable growth at regional level (Avram 2016).

The highest income stability among the analyzed countries can be seen in Germany. The most unstable in Greece. So The situation in Greece was less favorable, where both productivity and employment levels are very low. It is worth emphasizing that in Germany only one region (Braunschweig) has changed its position in transition matrices. It was moved to a higher range. In the case of Germany, no changes can be observed since 2010, later it happened for the other two examined countries. In Romania from 2015 and in Greece from 2016. The research has practical significance and the results can be used. Statistical data also shows that, as in the case of Greece, German regions are developing at an analogical pace. However, the hypotheses that GDP changes and development tendencies in regions are different, were confirmed. (Michálek and Výboštok 2018). In addition, Greece is distinguished from the other two countries (Romania and Germany) by the fact that its studied regions were classified as either in the lowest or in the highest ranges in transition matrices during the period considered. None of them was in the third or fourth income range (middle components) in the calculated transition matrices.

The obtained results may be a source of interest for people dealing with regional development issues. In the author's opinion, they should be treated as a new view on the verification of the dynamics of changes in the GDP per capita measure. They can also become an inspiration to deepen this type of 
analysis in the future, as well as an incentive to develop new, more in-depth methods sensitive to the slow dynamics of changes taking place in the studied regions. They are part of the overall research into the phenomenon of broadly understood socio-economic development.

\section{References}

Avram Costin Daniel, Avram Veronel and Avram Alexandru. 2016. Regional development in Romania - realities and perspectives. Political Sciences Law, Finance, Economics and Tourism Conference Proceeding SGEM 2016. BK 2. Vol. V. pp. 515-522.

Badoiu Catalina Mihaela. 2017. The Impact of EU's Structural Funds on Regional Development in Portugal. Sustainable Growth, Education excellence, and innovation management through vision 2020, Vols I-VII. pp. 3954-3965.

Goschin Zizi. 2017. Exploring regional economic convergence in Romania. A spatial modeling approach. Vol 8. Issue: 2. pp. 127-146.

Lai Sabrina and Leone Federica and Zoppi Corrado. 2017. Land cover changes and environmental protection: A study based on transition matrices concerning Sardinia (Italy). LAND USE POLICY. Vol 67. pp. 126-150 DOI: 10.1016/j.landusepol.2017.05.030.

Lewandowski Krzysztof. 2011. Ocena polityki regionalnej Unii Europejskiej w świetle badań empirycznych, Gospodarka w teorii i praktyce, Instytut Ekonomii Uniwersytetu Łódzkiego, Łódź, pp. 53-64.

Michálek Anton and Výboštok Ján. 2018. Economic Growth, Inequalities and Poverty in Slovakia from 2005 to 2015 (the analysis of relations and contexts at a regional level), European Spatial Research and Policy, Vol 25, No 1, pp.55-74. http://dx.doi.org/10.18778/1231-1952.25.1.04.

Muayedovich Kaziyev Valeriy, Valer'yevna Kaziyeva Bella and Yur'yevna Irina. 2018. Modelling of investment attractiveness and economic stability of region. The European Proceedings of Social \& Behavioural Sciences. pp. 2499-2509 https://dx.doi.org/10.15405/epsbs.2019.03.02.288.

Nadaud Emmanuel and Bouba-Olga Olivier. 2019. Beyond GDP per capita: the diversity of European regional contexts. Revue d Economie regionale et Urbaine. Issue 4. pp. 727-747

Podstawka Marian and Suchodolski Bartłomiej. 2018. Assessment of the level of economic and social development of regions using the Hellwig taxonomic development measure. VII International Scientific Conference Determinants of Regional Development. pp. 187-201.

Popescu Agatha. 2017. Convergence of Regional Development in Romania In Terms Of Gross Domestic Product. Sustainable Growth, Education excellence, and innovation management through vision 2020, VOLS I-VII. pp. 1279-1293

Surówka Agata and Prędka Paulina. 2016, PKB per capita jako wyznacznik rozwoju ekonomicznego regionów Polski Wschodniej - wyniki badań własnych. In Kowalczyk Lucjan and Mroczko Franciszek. 2016. Innowacyjność to rozwój. Zarządzanie operacyjne w teorii i praktyce organizacji biznesowych, publicznych i pozarządowych. Prace Naukowe Wyższej Szkoły Zarządzania i Przedsiębiorczości z siedzibą w Wałbrzychu, T.39(3), Wałbrzych, pp. 209-220.

Surówka Agata. 2015. Innowacyjność województw Polski Wschodniej na tle kraju In Pancer- Cybulska Ewa and Szostak Ewa. 2015. Unia Europejska w 10 lat po największym rozszerzeniu. Prace Naukowe Uniwersytetu Ekonomicznego we Wrocławiu, No 380, Wrocław, pp. 319-326.

Surówka Agata. 2015. Innowacyjność w województwach Polski Wschodniej jako kluczowy czynnik konkurencyjności w świetle badań własnych. Zeszyty Naukowe Uniwersytetu Rzeszowskiego pt. Nierówności społeczne z wzrost gospodarczy, No 42 (2/2015), Rzeszów, pp. 340-352.

Surówka Agata. 2014. Konkurencyjność województw Polski Wschodniej na tle regionów Unii Europejkkiej w świetle badań własnych. Zeszyty Naukowe Uniwersytetu Rzeszowskiego, Nierówności społeczne a wzrost gospodarczy, No 39 (3/2014), Wroclaw, pp. 394-407.

Surówka Agata. 2019. Ilościowa ocena dynamiki zmian wskaźnika PKB per capita w regionach Bułgarii i Słowacji. Economic and Regional Studies, Vol 12, No (2) 2019, pp. 127-135. https://doi.org/10.2478/ers-2019-0012

Muayedovich Kaziyev Valeriy, Valer'yevna Kaziyeva Bella and Yur'yevna Irina. Modelling of investment attractiveness and economic stability of region. 2018. The European Proceedings of Social \& Behavioural Sciences. pp. 2499-2509 https://dx.doi.org/10.15405/epsbs.2019.03.02.288 